
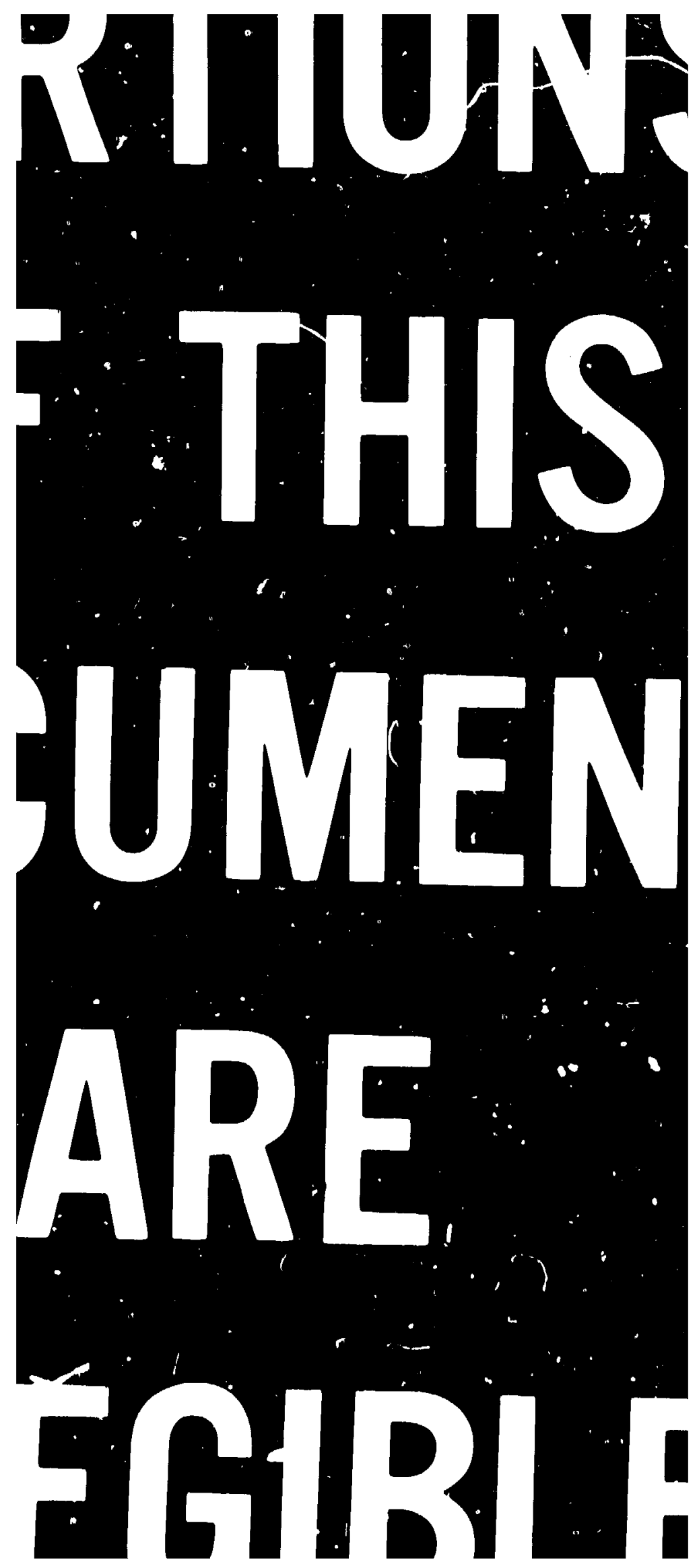
LA-UR -81-3620

\section{MISTER}

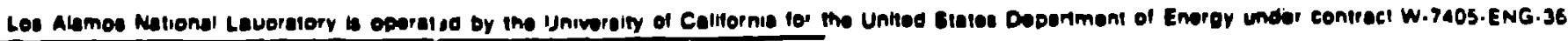

$$
\begin{aligned}
& \text { LA-UR- }-61-3620 \\
& \text { DE82 } 006155
\end{aligned}
$$

TITLE: STATUS OF LOS ALAMOS EFFOF.TS RELATED TO HIRCSHIMA AND NAGASAKI DOSE ESTIMATES

AUtmoR(S): P. P. Whalen, $\mathrm{X}-\mathrm{DO}$

SUEMITTED TO. DOE SYMPOSIIJM

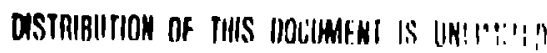

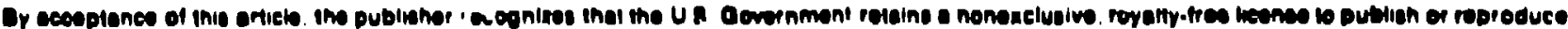

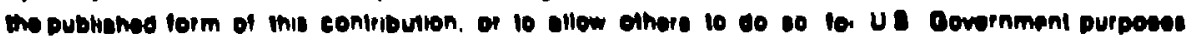

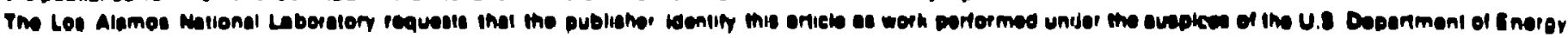

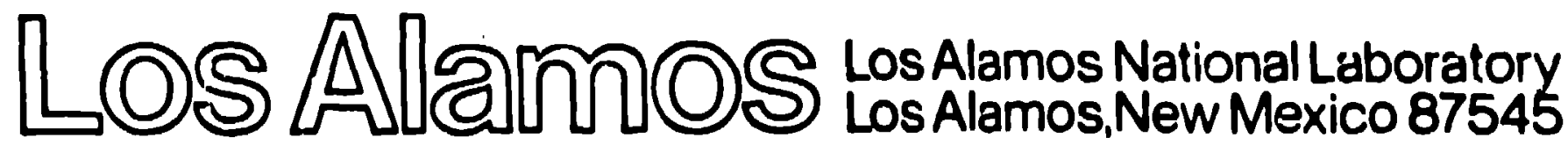




\title{
STATUS OF LOS ALAMOS EFFORTS RELATED \\ TO HIROSHIMA ANO NAGASAKI DOSE ESTIMATES
}

\author{
Paul P. Whalen \\ Los Alamos National Laboratory \\ Los Alamos, New Mexico 8754 S \\ September 1981
}

\begin{abstract}
In an unclasslfled summary fashlon, the Los Alamos efforts related to resolution of Lhe HIroshlma, Nagasakl doses will be deserlbed.

1. Yleld of the HIroshlima Bomb

Usling recentiv Lucated replloas of the Hlroshlini borab, measurements wlll be male at the l.osi Alamos Crllloal Asoembly laslllty (I.AC.11), whloh - In ronfunct lon whth calcalettons - - wlll deflate the upper llmle of the lll roshlma ylald.
\end{abstract}


2. Neutron and Ga...ma-Ray Output

Two-dimensional calculations of the neutron and gamma-ray out: uts of the Hiroshima and Nagasaki weapons are in progress. Neution and gamma-ray leakage spectra measurements will be made at the LACAF on the Hiroshima replica in a near critical configuratlun. Simllar measurements have lieen proposed on the Mark 9 wedpon and on the Ichiban assembly. These measurements, lilade with modern techniques, wlll provide a check for present day cross sectiolis and calculat tons.

3. Alr Transport and Grourid Efferts

Calculations of several alr trunsport experiments are In progress. Comparlson of calculated results wlth experlmental results are shown.

4. Debrls mutput

The neutron and gimmatray outplat spectr.d of soveral devfoes lested In the itmosihere at the Nevada Test stte ire beting calculdted. The results of these 


\section{$-3-$}

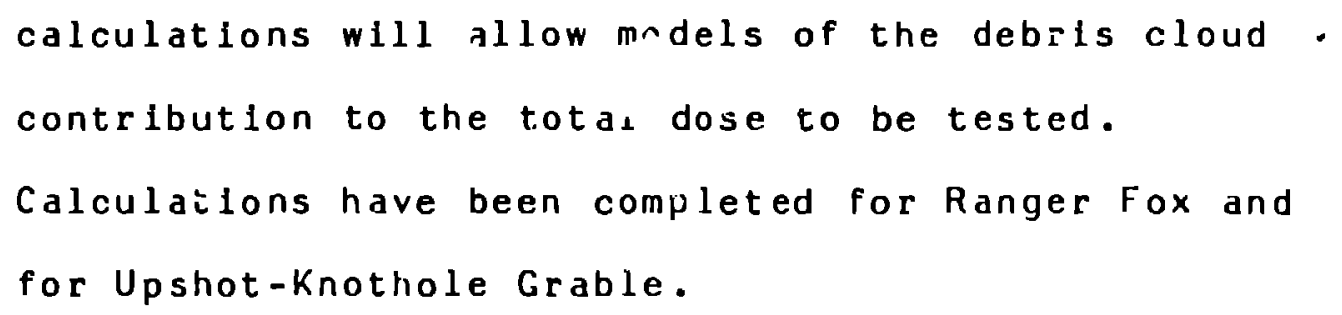




\section{INTRODUCTION}

Tha neutron and gamma-ray doses assigned to the atomic bomb survivors at HIroshima and Nagasaki must be accurate within scme limits if conclusions drawn from studies of the survivors are to have value. The doses recejved by the survivors depend upon the y!elds of the bombs, the speciflc radiation outputs of the bombs and of the bomb debris and the transport of the radiation through thic alr and shiejding around each survivor. In addition the self shlelding of the boly is important for many biological effact.s.

The accuracy of each element, of the dose assignment must be deinonstrated by comparison of pertinent calculated and observed dati rrom olher experiments and Nevada tests as well as whth physlcal data from HIroshjma and Nagasakl. To help in derlving dose assfgnments and demonstrattug thele accuracy, a smal program has been started at Los Alamos. Thls program is almed at helpiny resolve the question of the yiald of the lliroshima bomb. provialng two-dlmenslonal noutron and gamma-ray output for the Ill rosihlma and Nalisakl hombs, oxamlnlme lhe vallilty of alr trinsport calculalions and provlalue neuteon and gammaray output for some solected Nevidel test shots ro that the aseuracy of dose 
and spectra calculations can be demonstrated by comparison with observations.

The goal of the Los Alamos program is lo provide that missing weapons data which will allow the accuracy of dose calculations to be demoristrated.

I . YIELD OF THË HIROSHIMA BOMB

The bomb exploded at Nagasak1, the Fat Man, was a design that has been fircd in test situations. Yleld data is avallable from test firings of three wejpons nomlnally identical to the Nugasiki bomb, allowing good estimates of the yield of the Nagasaki explosion as reported by lohn Mallk in thls symposium. The bomb exploded at HIroshlma, the Littie Boy, was of a radleally different deslgn. Ther" have been no other test fleings of the Hiroshlma type weapon and no yleld measurements. listlinates of the yleld of tire lliroshlma expluston by different lnvestlgators uslne different blis of data have ranged between 1 . and 20 kt ilso di reported by Mallk. The ylold prodloted for the HLoshlma exploston was 15 kt (Schlff, 194b).

To supplement the on golne work by Mallk, Kerr, and others to resolve the dlffer int incegeretitlons of blast, thermal, and

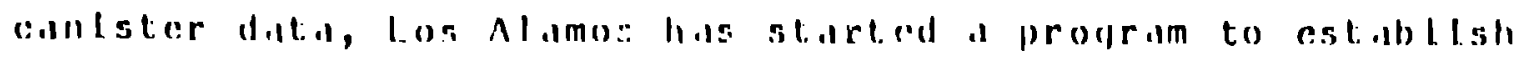

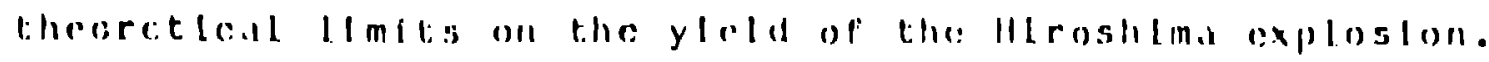


Obviously, if the bomb could be deslgned and the yield predicted in 1945 with the data avallable then, the yield can be calculated now with the wealth of data and calculational tools avallable now. However, as is often the case with good ideas, there is a problem with this one. All of tie data available 1 il 1945 is no longer readily avallable or is expressed in terms not sultable for our current calculational schemes. One of the crucial indeco critical - numbers available in 1945 is missing. This is the number that determines the criticality of the Little Boy assembly. Or course, the actual value used in 1945 for tine infinitely tamped mass of $23 b u$ is available as is the 1945 estimate for the criticality of Little Boy. What is missing are enoigh letails of the experiments and experiment analysis to cstimate the accuracy of the quoted values. And one very useful measurement was never made in 1945.

The yleld of the Hlroshlma bomb is very sensltive to the est Imate of crlticallty. Jensitivity calculations uslng a number of cross seolion sets avallable al Los Alamos resulted In a spread of ylelds from 8 lo $? 4 \mathrm{kt}$. Ustrin a subset of gencrally acoeplea cross sections resulted ln a spread of calculated ylelds from 1? lo $18 \mathrm{kt}$. These wore strletly sonsltivlty studles wlth no stgniflesuce lo be atenched to the central value. 
Nuclear archeolegy at Los Alamos would probably tirn up enough details of old experiments and analysis so that, coupled with a fairly complicated calculational program and pertubation aralysis, a good theoretical estimate of the Hiroshima yield could be prosuced. This estimate, however, would be subject to falrly large uncertainties because of the many steps in the calculational progran.

Fortunatejy, Los Alamos is in a position to prouuce a theorctical estimate of the maxlmum yleld of the Hiroshima exploston that is accurate to the norinal $10 \%$ qucted on directly measuied ylelds. This will be accomplished by doing the criticality measurement that was not done in 1945. The measurement wlll be dore In the Los Alamos Critical Assembly : acillty (LACAF). The Los Alamos Crltical Assembly Facillty is set up to allow two pleces of flsslle material to be brought safely toucther into a critical collfiguration. Most of the cilt lcil mass data avallable to the nuclear communlty was produced in thls faclitiy.

In May of 1981, four objects were Located In fleld siorage at Los Alamos. Three o: these objects were later ldent ifled by Harlow lluss, a rettred employee, as non-flsslle componenis of Litte boy wedpons whloh had leen retired from stockplte. 
The fourth object was a trainjng device without the proper materials. Harold Agnew, the former Director of the Laboratory, had wisely stored these four samoles. These components were transferred to the LACAF.

After the publicity in June concerning the Hlroshima1. asaki doses, it developed that several people in the Laboratory knew of the exictance of these components but had not been aware of any intereit in them.

Fissile parts have been ordered which will allow a direct experimencal determination of the criticalily of the Little Boy In the LACAF. With this informaticn, a caloulation of the maximum yield is straightforward. The calculated yield is of necessity the maximum yleld because of the possibllity of a malfunction of the Hiroshlma bomb. Even witn this limitation, an accurate theoretical value for the maxlmum yleld will be very valuable. A low theoretical value exclucles the higher yields Infired by other technlques. The effect of a hlgh theorelical value ls not so cleall. However, a high theoret leal value for the yleld would indloate with high probabllity that lechnlques whlch Infer lower yields should be crltcicily examlned.

At this polnt, it always appears that the dlrect solution to the questlon of the Hlroshima yleld is to simply fire one of the 
Lictle Boy replicas ard measire the bleld. This is easier sald than dorie Because of the problems ur mejsuring gields of this r.pe of device fa ar undergrcund environment, the direrty measured yeld toule have very large error bars: larger than tre error bars associated with the program we are folloning. The Interprecation of other test diggriostics supled with ealeulations would reduce the error bars to 1īis. Honierce, elen a simple test mold cost an order jf magritule minte than the measirements in the LtCA: .

For the determination of arse, the regl gufetion is rot the gield ớ the Hirushima bomb, but the rieutrin ana qamma-ra: autert of the tuint arid the output of the debcis cloud. The mi-jourement

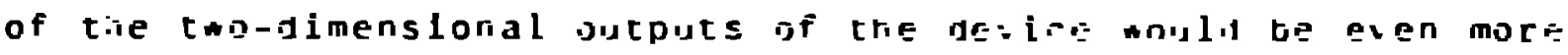
expenslie than a yifld measuremert in an underugurud erioironmetil and there are real problems with mensurements off debris clatud in undergrounf envirorments.

There are two mort activities to bi deseribrat a progr.um or

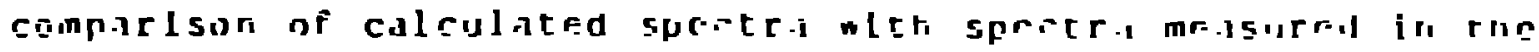

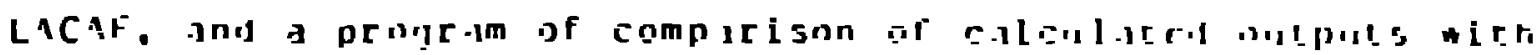

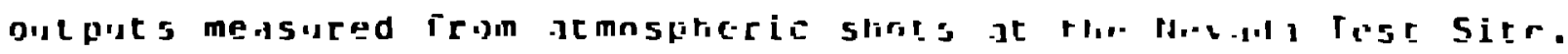

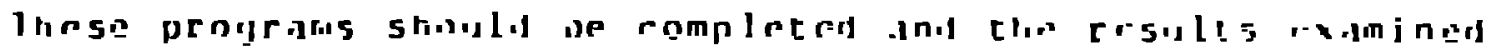

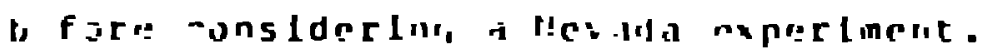


III. NEUTRON AND GAMMA-RAY OUTPUT

Los Alamos is doing two-dimensional calculations of the neutron and gamma-ray output spectra of both the Hiroshima and Nagasakl bombs. The Hiroshima bomb calculations are in progress. The Hiroshima bomb was much more two-dimensional than the Nagasakl bomb which was nearly spherical. Thus more interest attaches to thr Hiroshima bomb calculation.

\begin{abstract}
Calculations of the neutron output of the HIroshima bomb werc done by W. Higgers of Los Alamos in 1962 with 11 mited release to the effects community. Ho report of the results nor other documentation of these calculations has been found. Some records may exlst in dead storage. These calculations are mentioned only becal, c the neutron output appedrs to have been usod before for dose estimates at Hiroshlma.
\end{abstract}

In 197b, W.t. Prece of Los Nlamos did ond-dimensional (spherleal) caleulat lons of the neutron and gamma-ray output

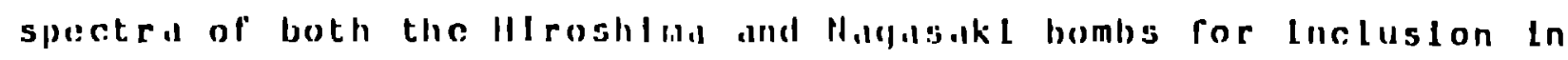

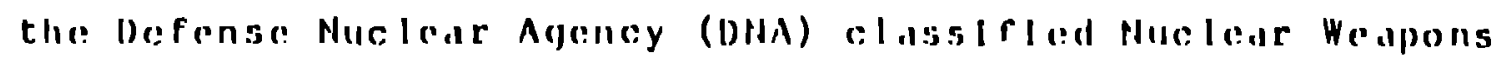
Output Handbook. These output speetra were dectisslfled by the Do)! In 1976 and publlshed is a lellor to C.P. Knowles. Because 
these output spectra are the starting point of all of the re-analyses of dose which have been done to date, the letter is Iricluded as an appendix to this report.

In the Preeg letter, In addition to the output data, are comparlions of dose as a function of distance with the dose inferences of Hashlzumc et al. The Preeg doses are not valid. The doses were not calsulated in an alr-over-ground geometry but came from a mode! for Infintie alr transport and we r done for

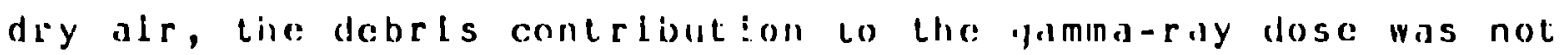
Included and the Nalgaskl helght of burst was lnoorrect. This is all polited out le the letter. The dose walculations were not pursued rurther.

With the revival of Interest In the Htroshlma-llatgankl doses

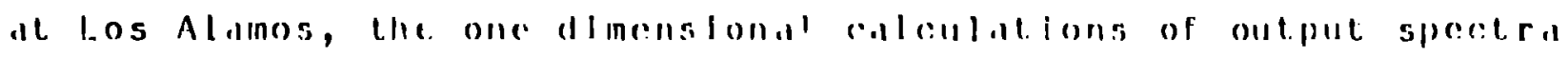

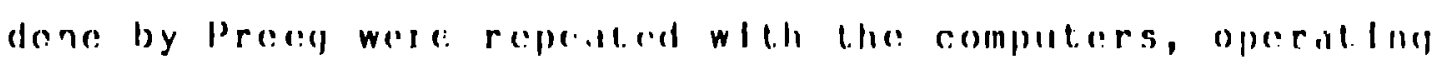

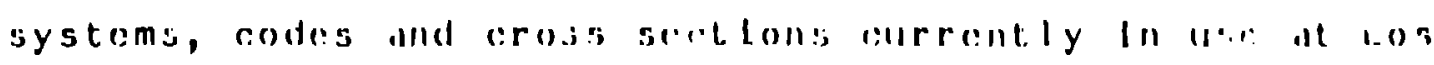

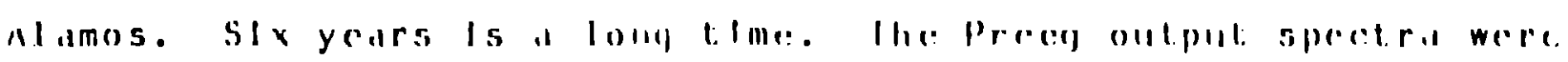
anflemall.

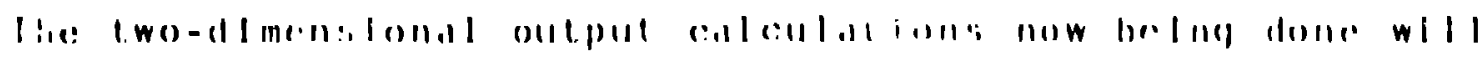

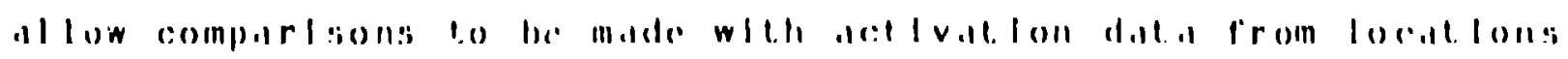

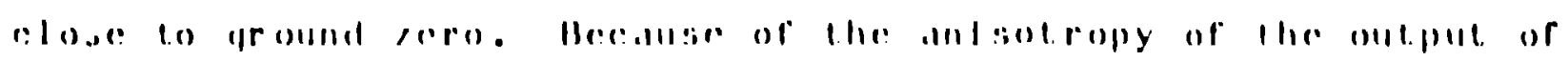


the Hiroshima nomb, these comparlsons could not be made before. These comparisons wil: be a new test of the validity of the calculat lons.

To provide calibration data for tr.c output spectra calculatlons, neutron and gamma-ray spectra medsurements will be made at the LACAF on the Hiroshima repllca in a near critical conflguration. These medsurements, made with the best technjques uvallable, wlll provlde yet another check of codes and cross socetlons. The speetra mensured at the LACAF on a cold static assembly ire not the spectra of on expiciding bomb. Hlgh energy

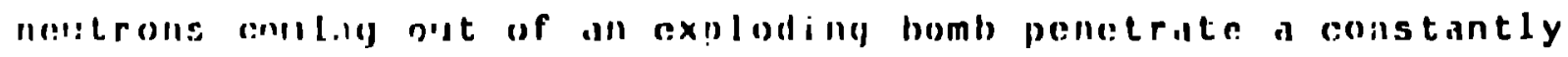

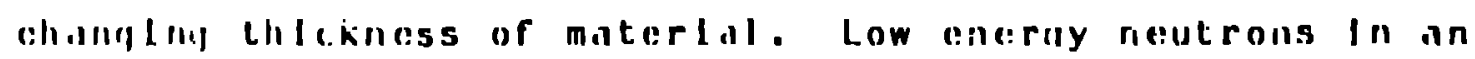
explodlne bomb experlence a thernal envlronment very different from the thermel environment of a shatle assembly. Special purpose reofes have been developed lo handle lhese offects.

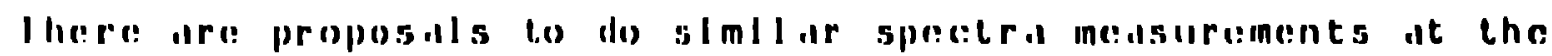

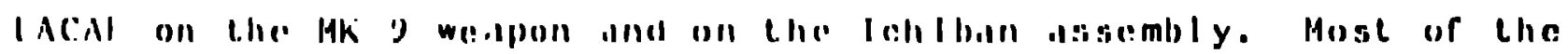

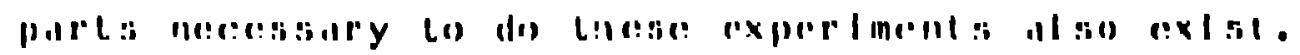

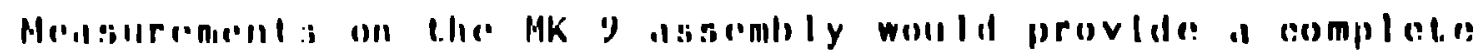

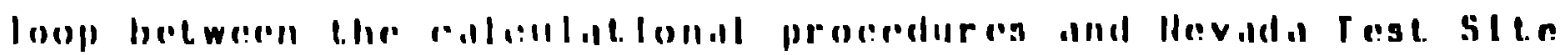

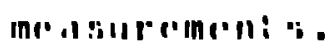




\begin{abstract}
Measurements on the Ichlban assembly wuld resolve a long standing buc little known problem. In addition to there being two different calculated neutron speccra for the Ichlban experiment (which has been reported), there were two dlfferent neutron dose measurements made on the Ichtban assembly. Only orie of the measurements was reported. Modern measurements would clear up the discrepancy.
\end{abstract}

\title{
IV. AIR TRANSPORT CALCULATLUIS
}

l.os Alamos has ong of the premler trantsport calculatlonal capablitites In the country. The Los Nlinos MCNP eode ls a cont Inuous crergy Monte Carlo colle ror couplod neateon and

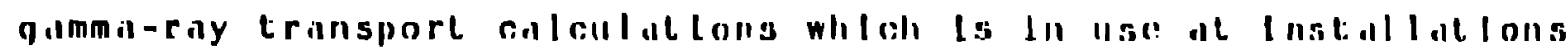

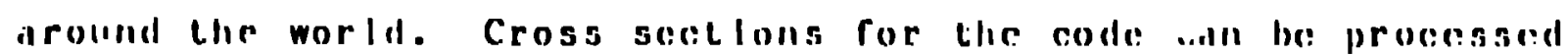

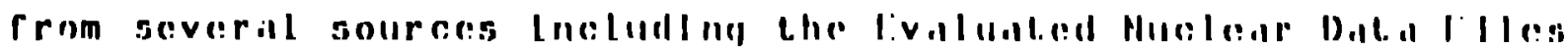
(I.Nu) Ibriry. Milny of the reatures of the MCNI colle and reas

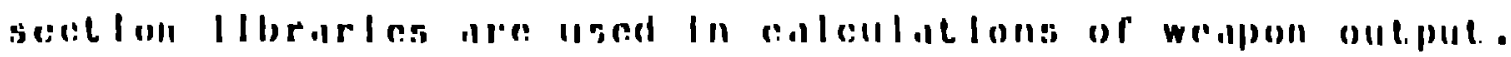

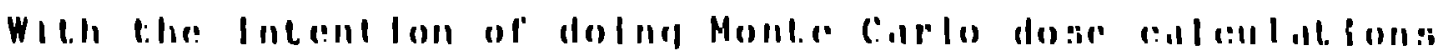

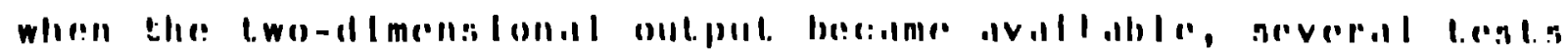

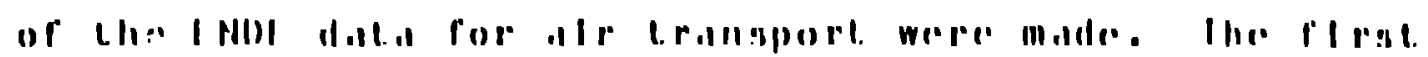

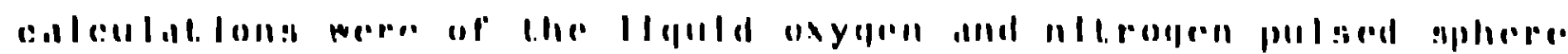

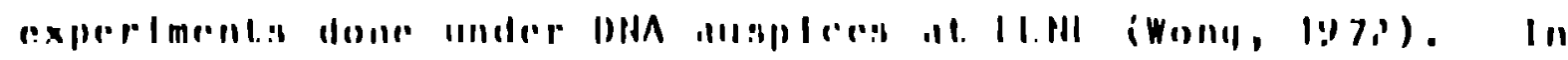


the ue experiments a pulsed source of DT neutrons is generated in the center of a sphere of the material to be tested. Neutrons emerging from the surface of the sphere are counted by time-offlight techniques. Typical results from these calculations with E.NDF cross sections were that calculated and measured total neutron fluence between 2 and $14 \mathrm{MeV}$ agrced to better than $10 \%$. However, discrepancles up to 50 w werc seen In sub intervals of the energy spectrum. Cencrally, the calculated fluences were low at high energies and hlgh at low elergles. The results of a typleal calculation are shown In flqure 1 with the tlme-of-filght. spestrum it the to, and the conergy speotrum at the bottom.

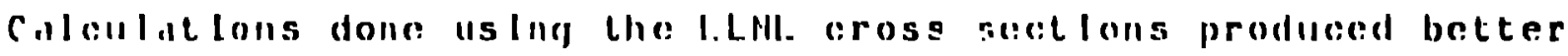

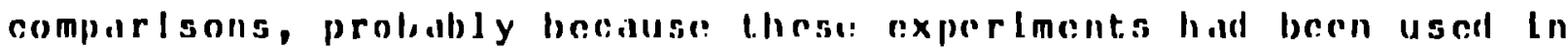

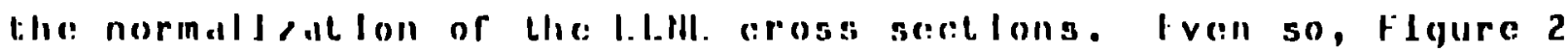

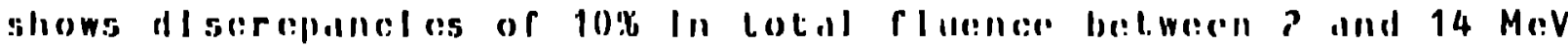

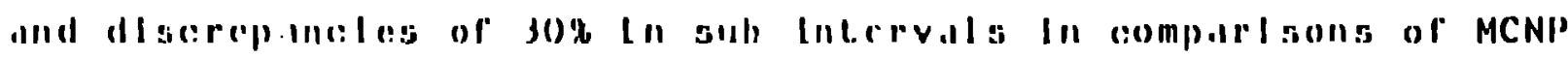

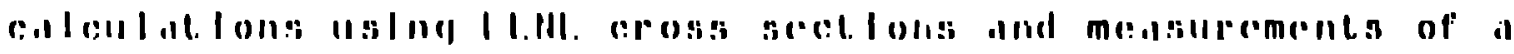

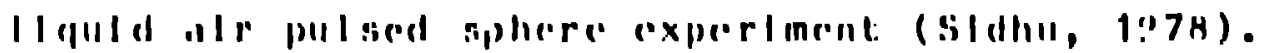

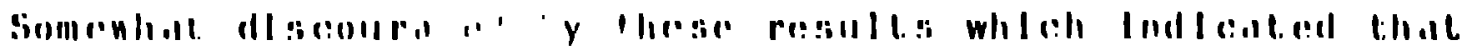

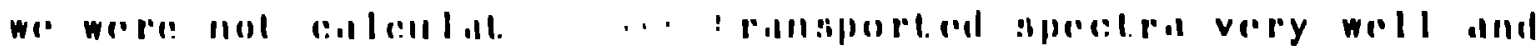

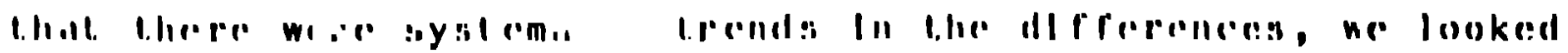

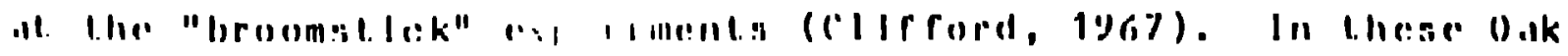

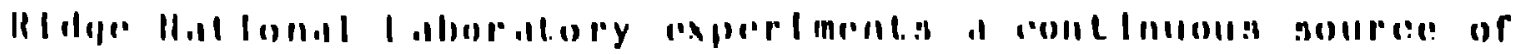


neutrons from a port in the Tower Shlelding Reactor II Impinged on one end of a thin cyllnder of the material under investigation. Neutrons emerging from the other end of the cylinder were counted In an eneryy discrimination mode. The result is a rather clean transmission experlment. Again, calculations with ENDF cruss scetions of the neutron tiranmission through liquld oxygen and nitrogen were disappolnting. The calculated fluence tencied to be low at high chergles. In addlion, the calculated valleys in the trangmltiod fluence through nltrogen dla not agrege Ln mijnilude (factor of two) nor In energy (104-2016) wlth the observed valleys. The comparlsoris of calculitions with observation are shown lil flgure 1 . In thls flqure the snake across the fleure ls the error billil of the:

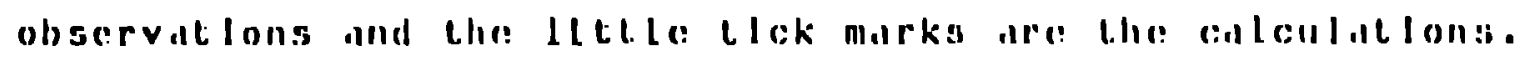

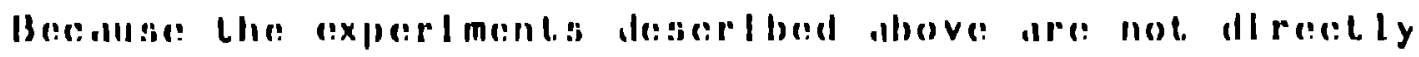

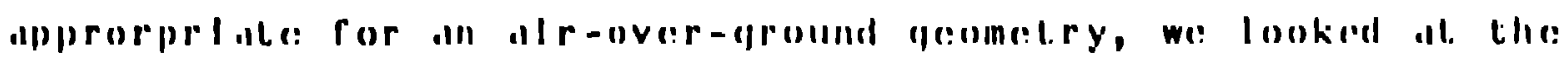

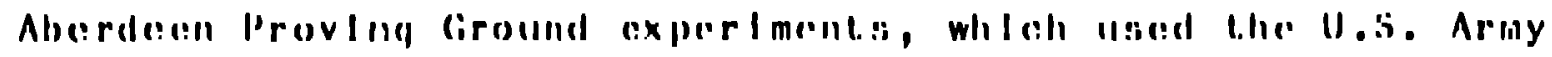

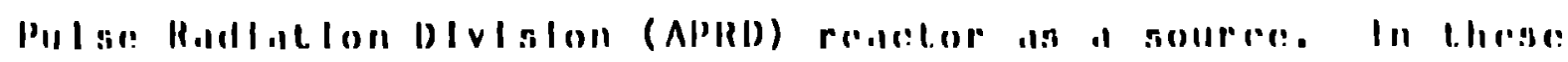

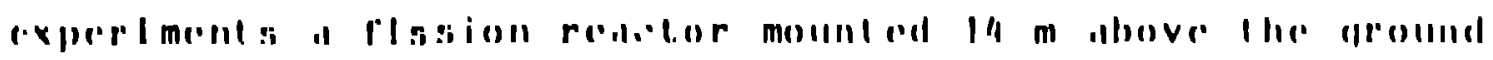

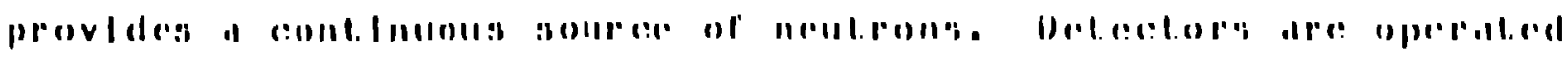

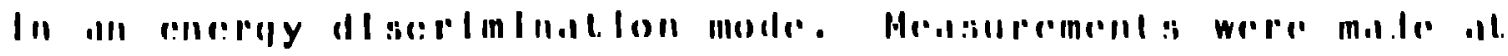

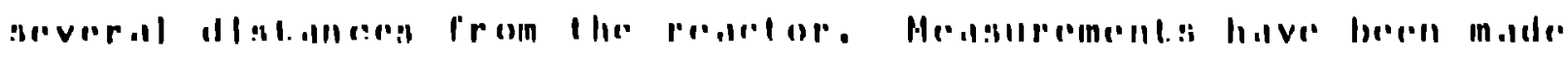

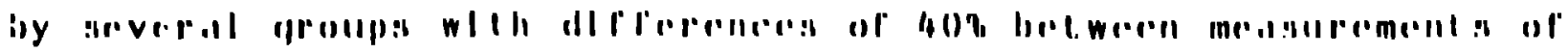


different groups (Robltallle, 1980). However, If the measurements of the different groups are compared $t$, the average of all the measurements, the Individual measurements are within $20 \%$ of the average over the energy range .6 MeV to $10 \mathrm{MeV}$ as shown in Figure 4. In contrast, the Los Alamos MCNP calculations of flurence using the ENDF cross scctions fall well outside the $20 \%$ deviation from the average of the measurements and show a strong enargy dependencis. The Los Alamos calculated fluencer ire $\sim 40 \% 6$ below the averige of the measurements it ingh encegles and $\sim 40 \%$ ahove the averaye at low energles as shown In Flgure b. Also shown on Pleure 5 are the fluences cialeulated whel the $5_{n}$ DOT

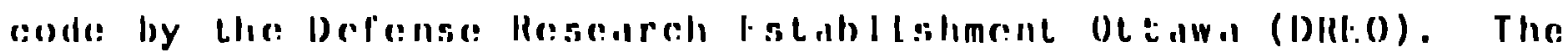

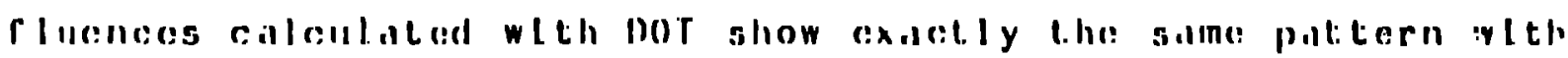

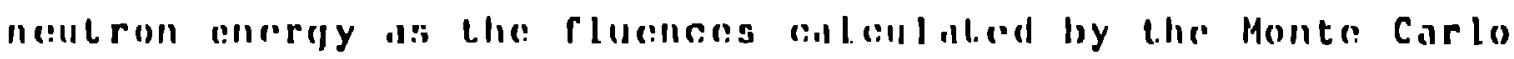

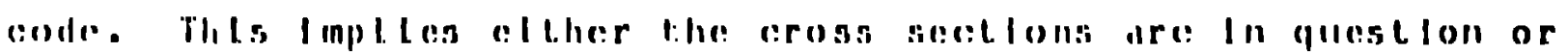

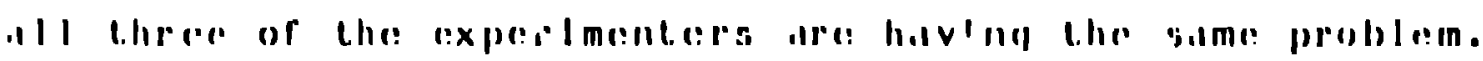

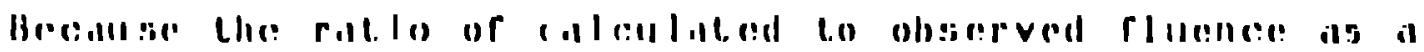

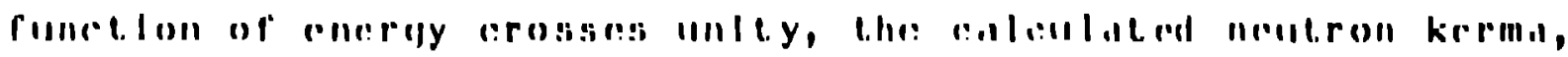

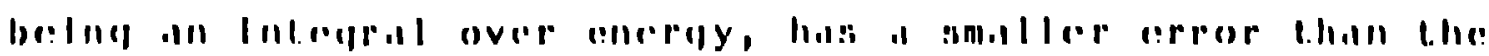

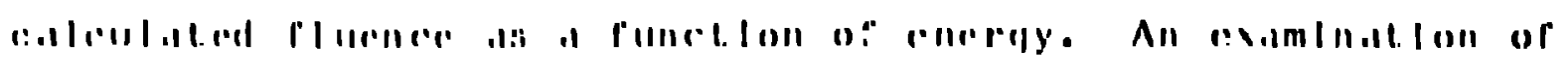

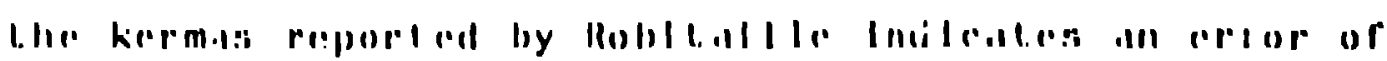

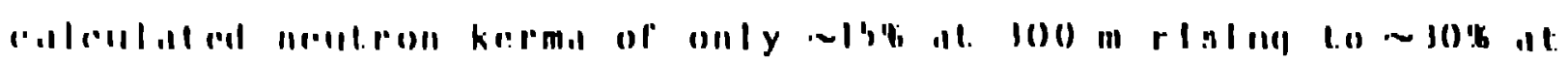

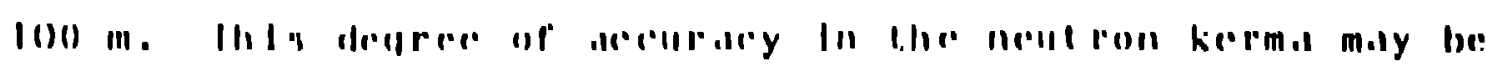




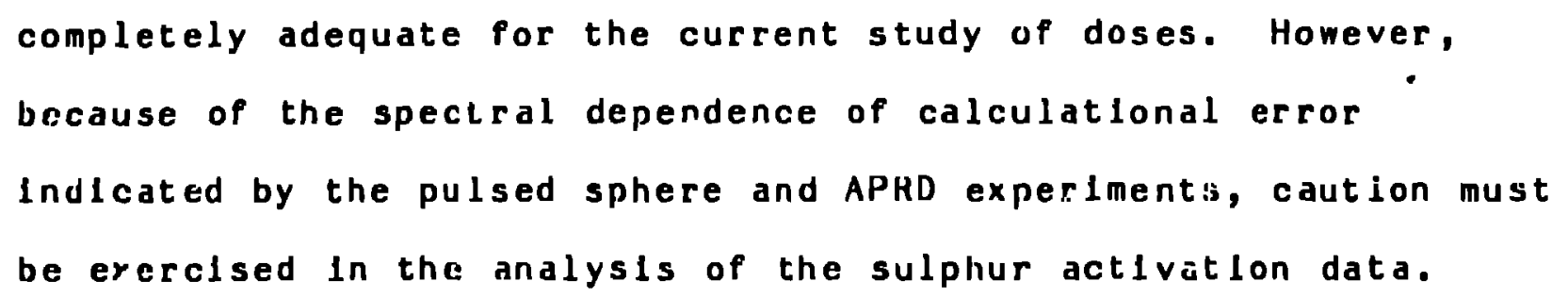

Gammal rays from the debrls cloud of a nuclear explosion contrlbute an appreclable fraction of the total dose on the qround at the ranges of Interest at HIroshlma and Nagasakt. The modelltng of the yommo-rily dose from the llobrls is not done as

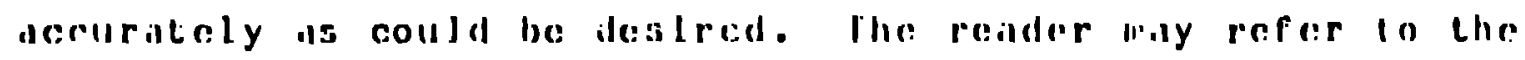
dlsousstons of thls lople by Korr and locewe In thls symposlun. ro help In the callbration of more acecurate debris models, tos Alamos wlll provlale the caleulated prompt neulron and gamma-ray

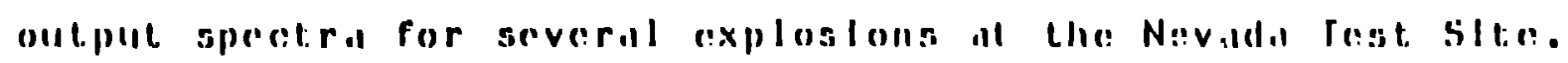

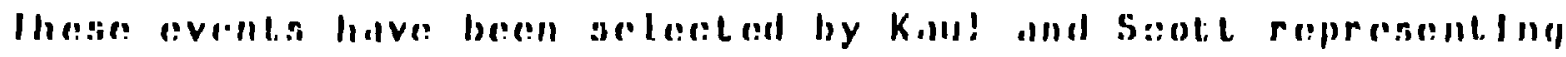

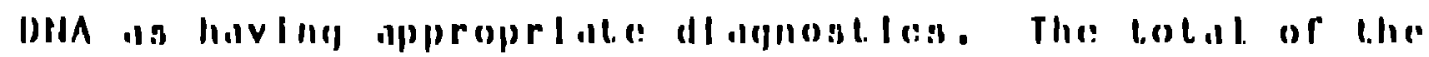

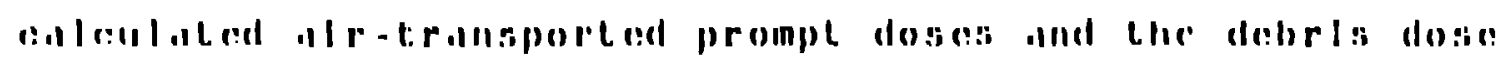

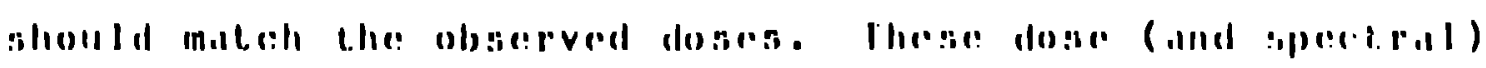

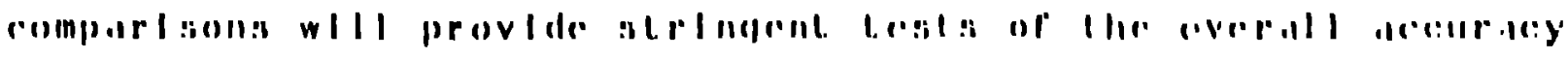

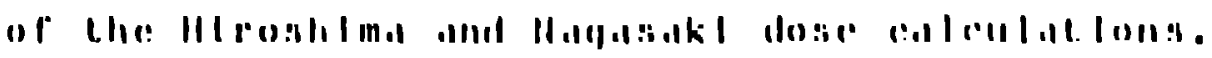

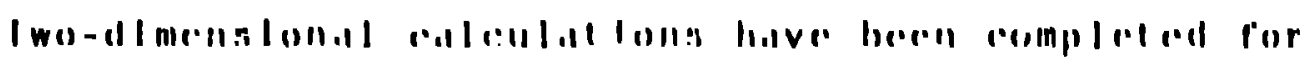

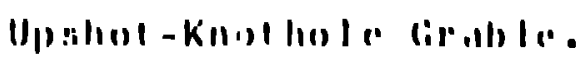


One-dimensional calculations have been completed for Ranger rox.

other calculations will be completed as manpower permits. Thesc calculatlons are not difflcult; locating drawlins and specifications for these old shots is slow und time consuming.

\section{ACKNOHLEDCMENTS}

The allthor wlshes to thank the followlng Los ALamos indlviduals who have donc all of the work reportea In thls paper.

X-4 Nuclaar Appllat' Lons

H. Houers and for 1-dImensional models and exploston H. Wor!ton billeulitilons

a. Kaminerdlener for d-allmensional explosilon raloulations of Lha II!rosillma bounh

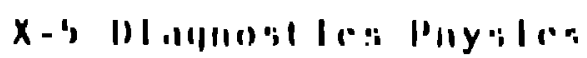

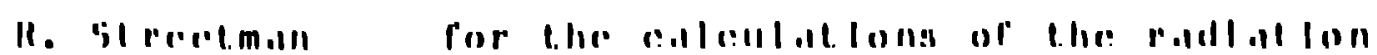

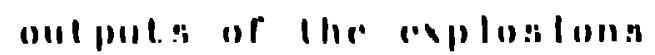


X-6 Monte Carlo

p. Soran

for providing cross section sets

R. Seamon

for providing, modifying and checking cross sections

R. Little

for thc "broomstick" calcu at lons

G. Estes

for the pulsed sphere and iPRo calculations and the metliod of fata presentation

Q-14 CrIt:Lal AssembJ10s

R. Malefane for enthustastle support from the Critical Assembly liatlity

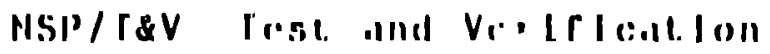

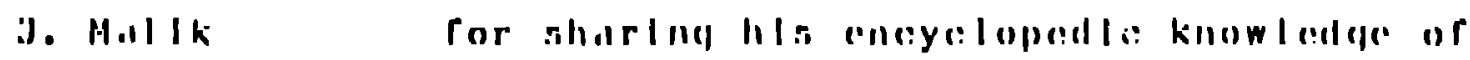

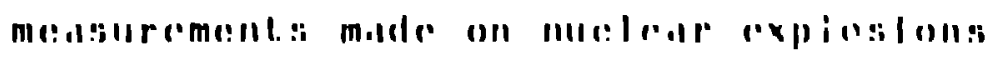

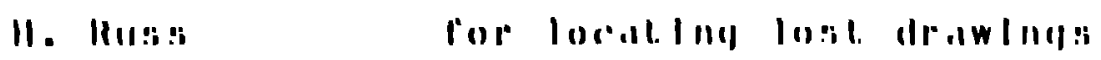

$(\ln 1, \ln (\cdot)$

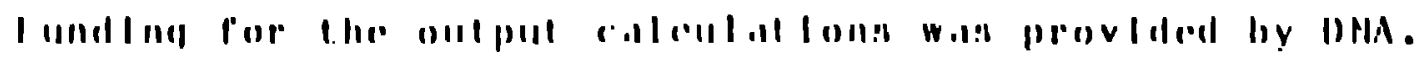




\section{REFERENCES}

ClIfford, C.E., E.A. Straker, F.J. Muckenthaler, V.V.Verbinskl, H.M. Freestone,Jr., K.M. Henry and W.R. Burrus, 1967, "Measurements of the Spectra of Uncollided Fission Neutrons Transmltted Through Thick Samples of Nitrogen, Lxygen, Carbon and Lead: Investlagaton of the MLnina In Total Cruss Sections," Nuclear Sclerice and Englnocrl. J, 27, Oak Ridge National Laboratory.

Robltalle, H.A, and B.t.. llogfarth, 1980, "A Comparlson of

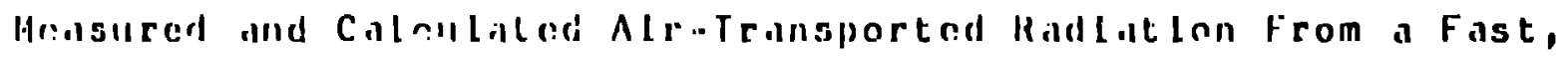

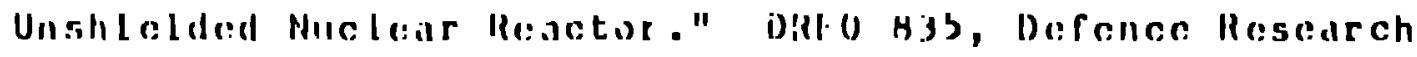
I.slab) Ishonent: altiw.l.

sohlff, I..l., August 4, iy4b, "l.xposted porformance of the cun

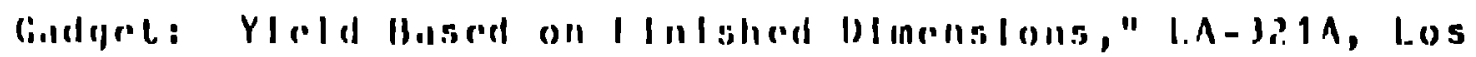
Alinos, (SI ERI I HISTRICII) DAIA).

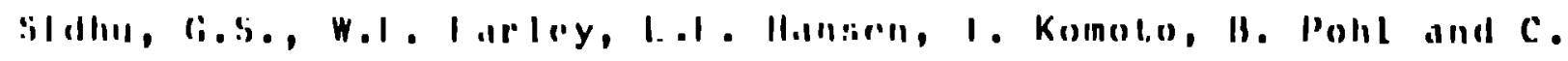

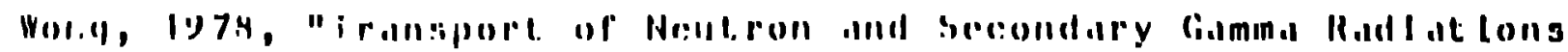

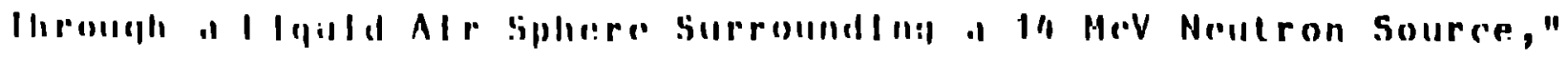

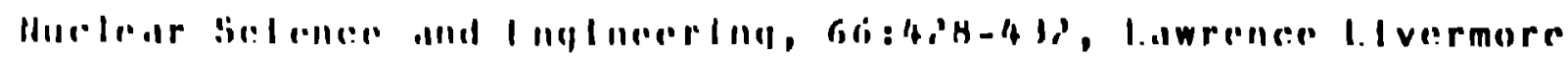
l.thor.110ry. 
$-21-$

HEFERENCES (continued)

Hong, C., J.D. Anderson, P. Brown, L.F. Hansen, J.L. Kammerdiener, C. Logan and B. Pol, 1972, "Livermore Pulsed Sphere Program: Program Summary Through July $1971, "$ UCRL-51144, Rev. 1, Lawrence LIvermore National Laboratory. 
Captions for the Illustrations

Figure 1. Spectrum from Liquid Oxygen Pulsed Sphere

Figure 2. Soectrum from Liquid Air Pulsed Sphere

Figure 3. Spectrum Transmitted through Nitrogen

Figure 4. Comparison of Measured Spectra from APRQ Heactor

Flugre 3. Comparison of Calculaled Spectra from Alpu Reactor 
LIQ. OXYGEN, ENDF5
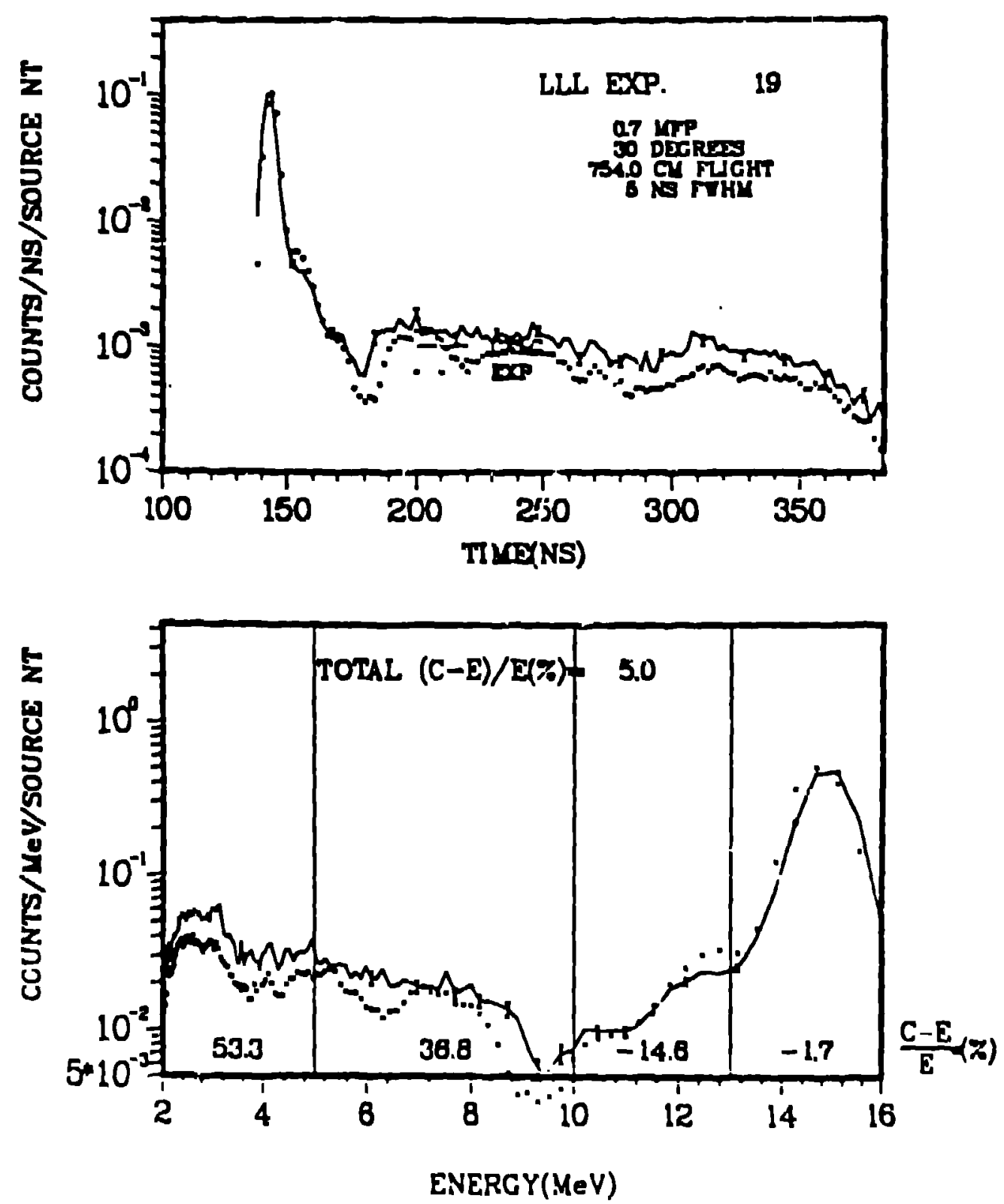

Finure! 

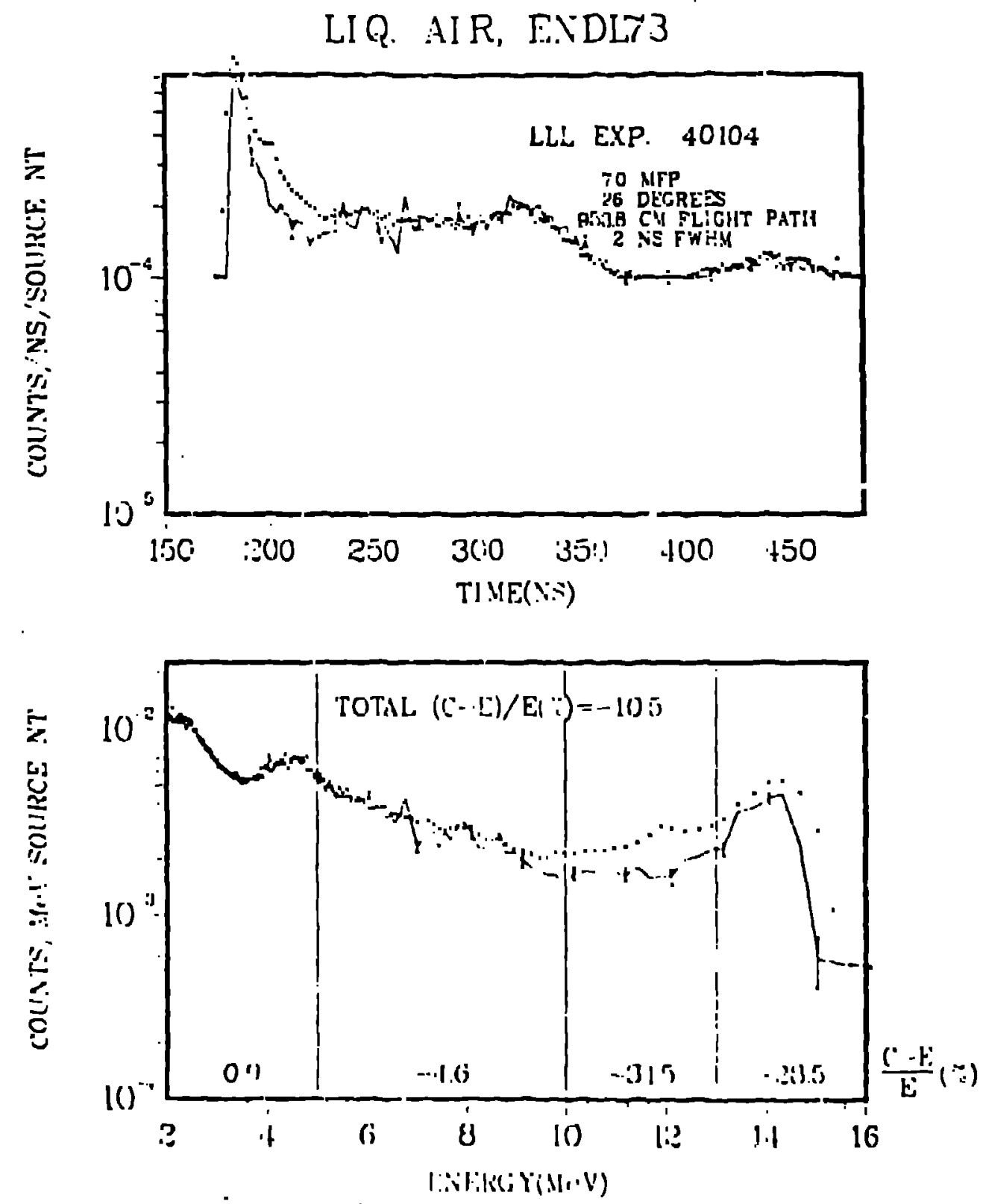

Flpiure 2 


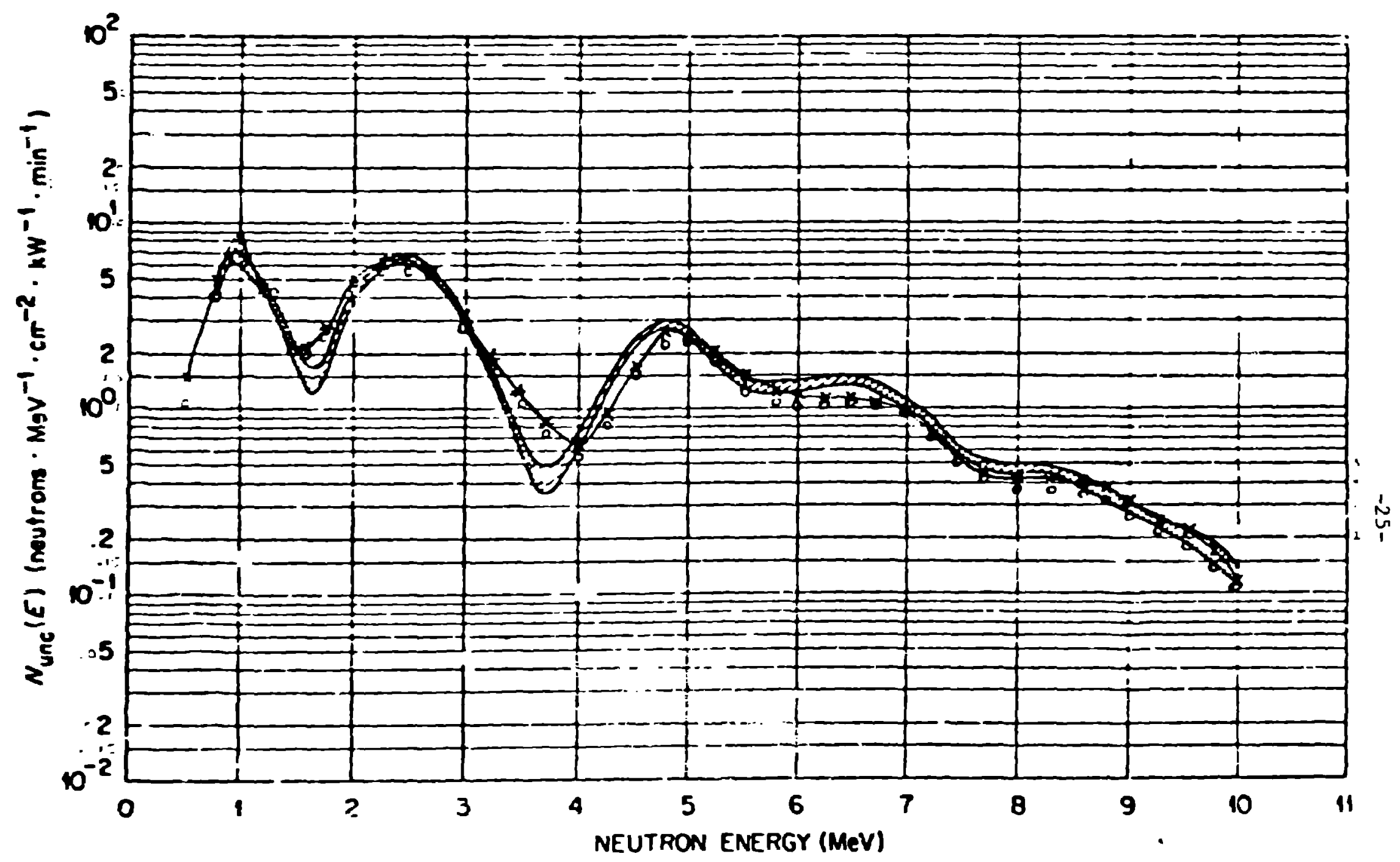

Fig. 3. Transmitted Spect in Through Nitrogen. 


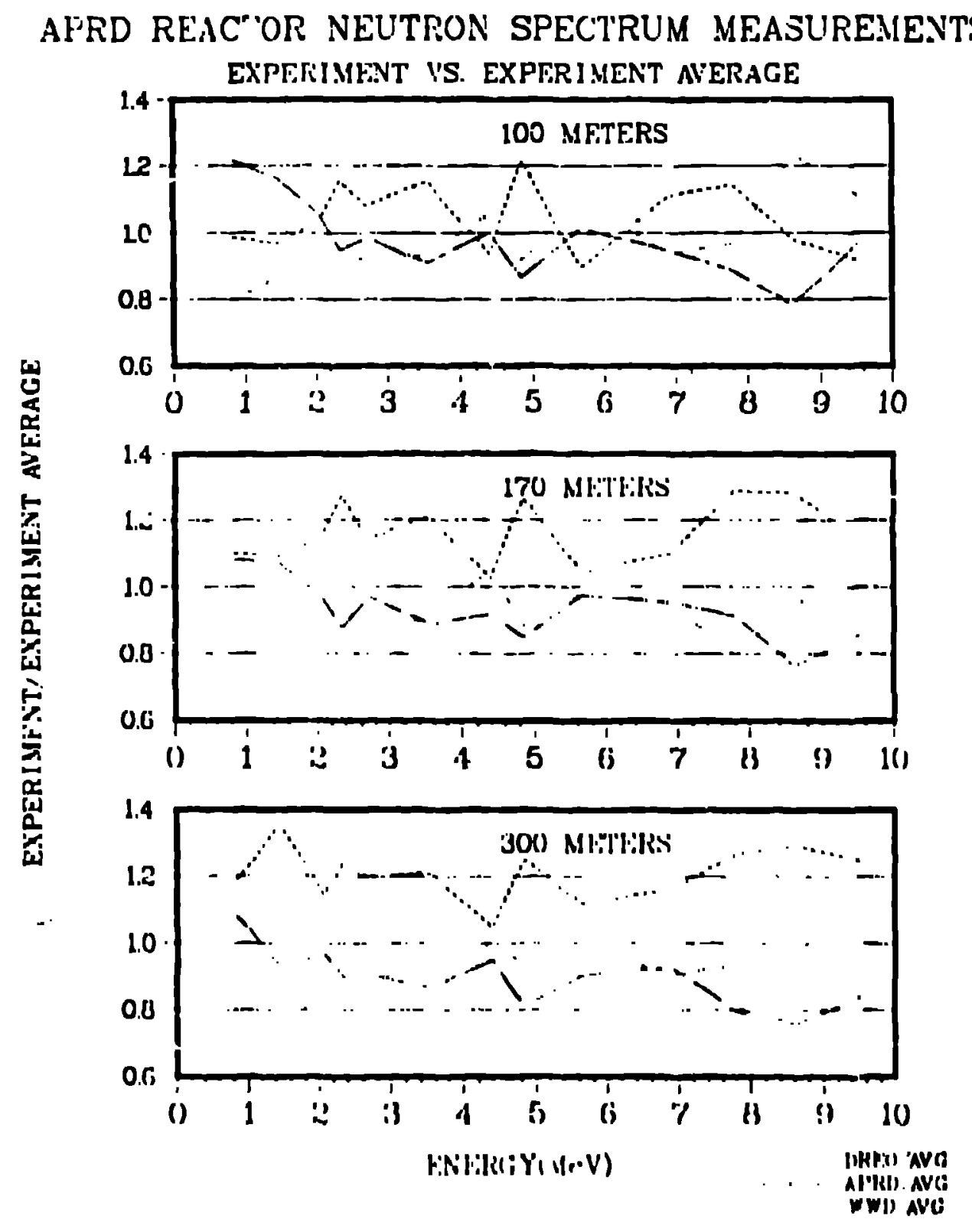

I' I!!11 


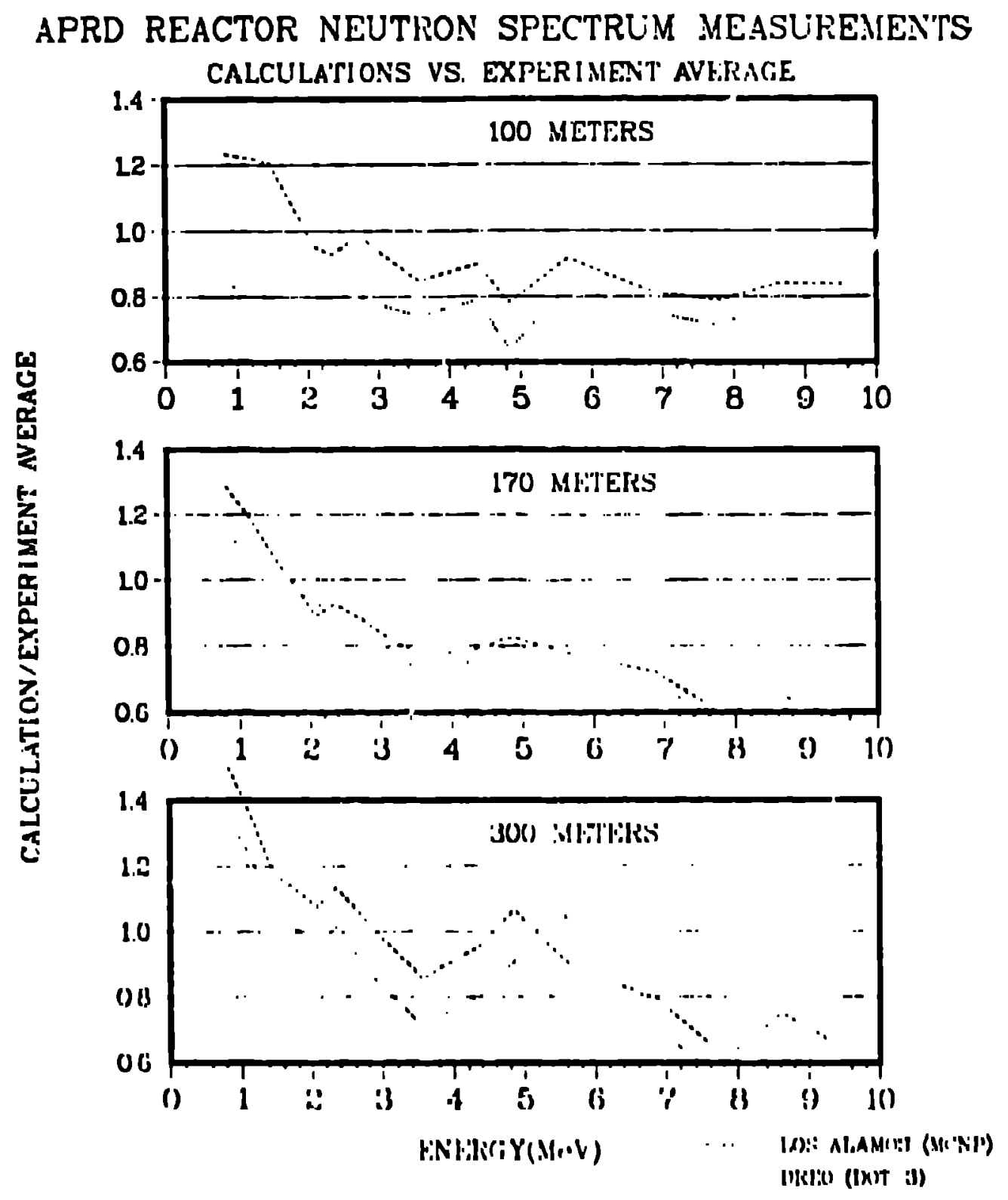

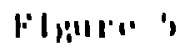


APPENDIX

Memorandum datcd, Apr11 b, 1976, to Dr. C.P. Knowles from W.t. Preeg. (8 pages) 


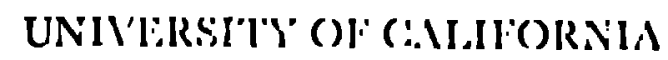

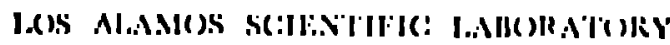

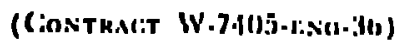

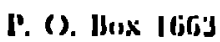

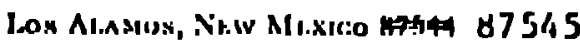

IN RFI'LY

HATr.k 7o. TD -3

MAII. STCI: : 1.S 232
Apr 115, 1976
Dr. C. P. Knowles

$R$ and D Astiocliates

l. O. Bux 9605

Marlini del Ruy, Ch 90291

र $17 \%$

TIllu: R. N. Thorn, I'D-IDO

Dear sklp,

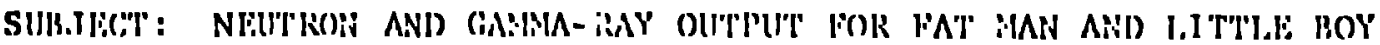

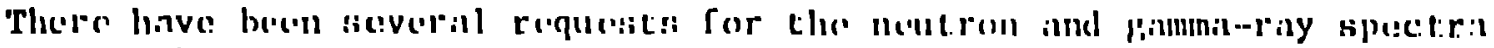

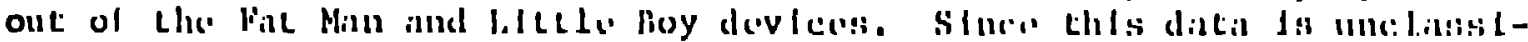

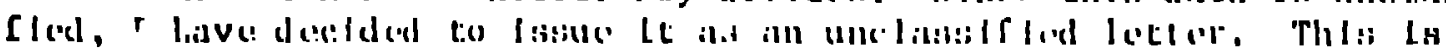

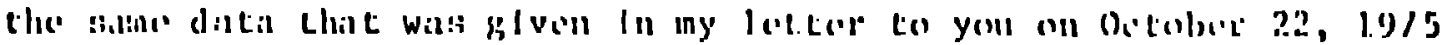
$(11) \cdot-3: 7 \cdot 3-87)$.

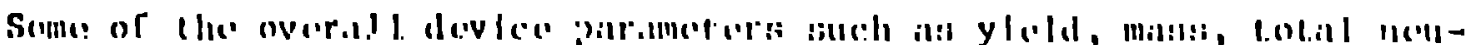

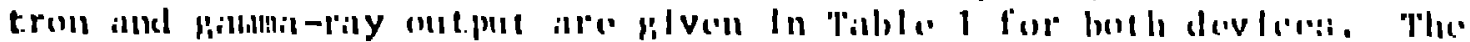

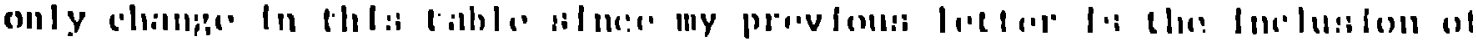

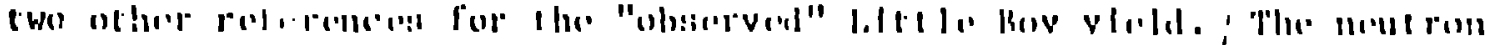

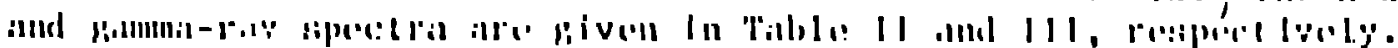

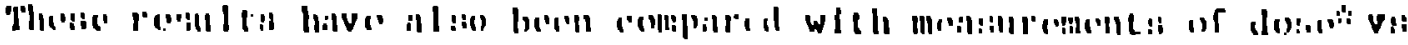

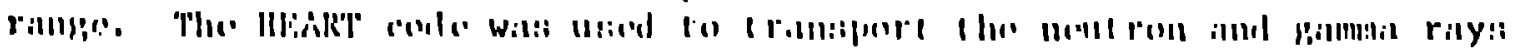

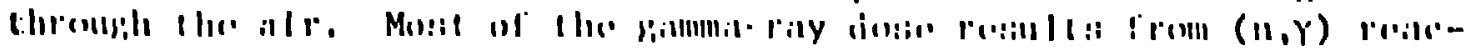

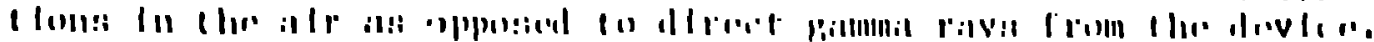

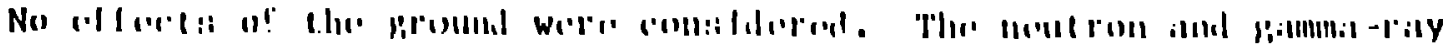

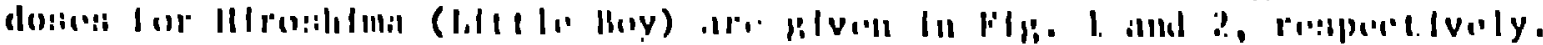

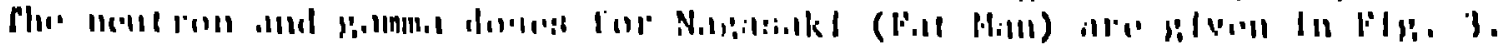

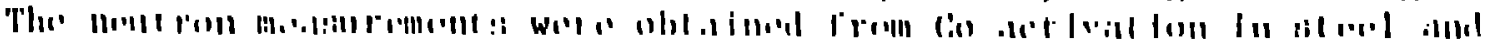

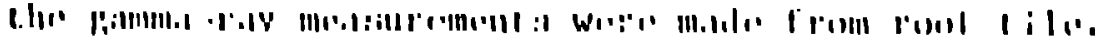

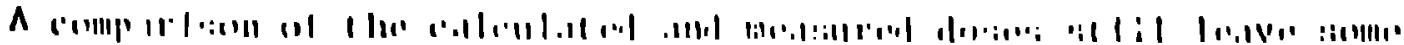

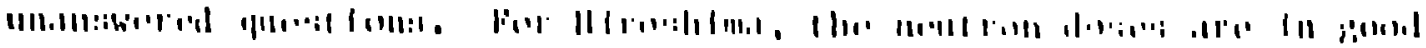

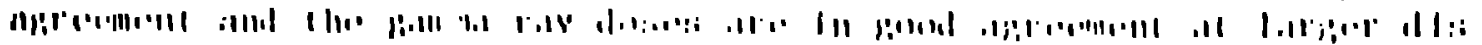

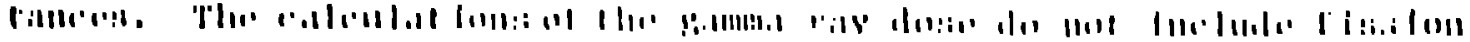

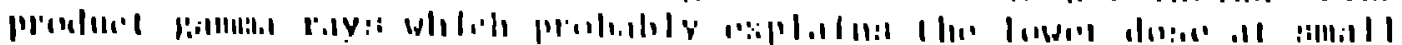

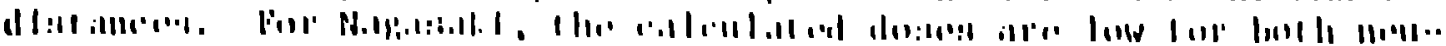

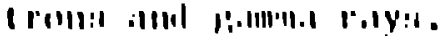

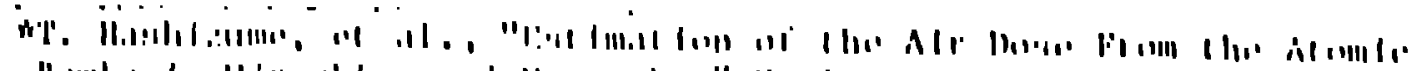

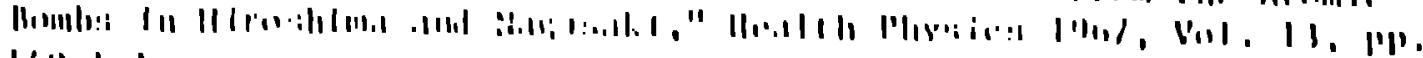
$|i n \cdot| 1, \mid$ 


\section{TABLE I}

- fat man and little boy device PíRumeters

\section{Fat Man Litile Boy}

Calculated Yicld (kt)

24.9

$19.5^{b}$

Observed Yield $(k t)^{a}$

Mass (kg)

Neutron vutput (moles/kt)

Averige Energy of laikilge: Neutrolii (MoV)

Gamma-Ray Effleiency（ $(z)$
22

4700

0.28

0.010

u. 095
$14-18.5$

4050

0.21

0.315

$0.0 \div 4$

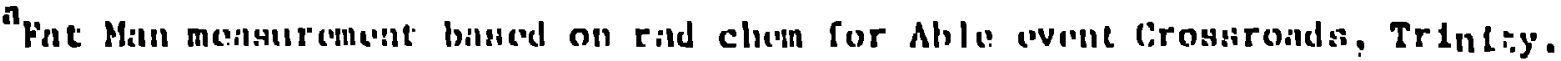
littie Bny yledalsi are fiven in the followlug reports: IA-1398, "Ylold of the Ill rusihlmil Hoith," Apri] 18, 1952.

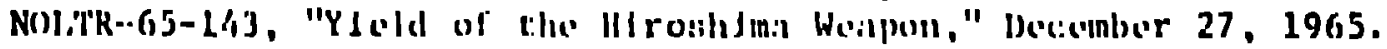

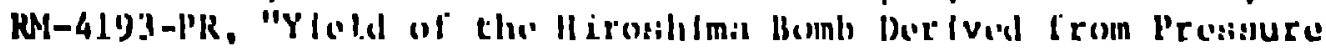
Record," sepelember 1.0624 .

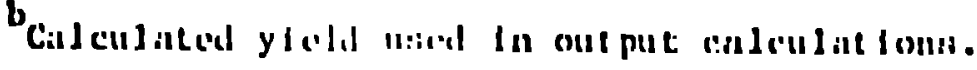




\section{TATILE II}

NEUTION C:ITPUT SPECTIA

\begin{tabular}{|c|c|}
\hline \multicolumn{2}{|c|}{$\begin{array}{l}\text { linergy Group } \\
\text { (IleV) }\end{array}$} \\
\hline 0.07 & -7.79 \\
\hline 3.68 & -6.07 \\
\hline 2.865 & -3.68 \\
\hline$? .232$ & $-2.86,5$ \\
\hline 1.738 & -2.232 \\
\hline 1.353 & -1.733 \\
\hline 0.823 & -1.35 .3 \\
\hline 0.500 & $-0.8:: 3$ \\
\hline 0.303 & -0.500 \\
\hline 0.38 .14 & -0.373 \\
\hline $0.701:-2$ & $2-0.18$ in \\
\hline 2.1801:-2 & $2-0.761:-2$ \\
\hline $9.13 \%-3$ & 3 - $2.14861:-2$ \\
\hline $3.351:-3$ & $3-9.13:-3$ \\
\hline 1.2.1.1.:- & $3-3.3 .34 .-3$ \\
\hline 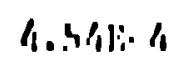 & 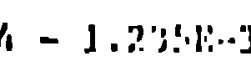 \\
\hline J.6.61:- & $1-1.111: 4$ \\
\hline $0.1 / 1, \cdots .5$ & $5-1.0615-4$ \\
\hline 2..8(1);:- ; & $j-6.11, i:-. j$ \\
\hline 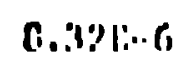 & o \\
\hline $3.061: \cdots 6$ & 6 \\
\hline d.1.31: i & $i=3.13(1):-i$ \\
\hline A. Jו1:-.7 & $y-1.1 .11: \cdots$ \\
\hline
\end{tabular}

\begin{tabular}{|c|c|}
\hline \multicolumn{2}{|c|}{ Neucron 0:ur pur: } \\
\hline Fat Min & Litela: ling \\
\hline $1.33 \mathrm{~F} \cdot 21$ & $1.861 \% 2.1$ \\
\hline $2.741 \% 121$ & $7.11 .1 \%+21$ \\
\hline $2.2 .0 F:-1 \cdot 21$ & $8.5(1): 1 \cdot .1$ \\
\hline $3.77 k:+2.1$ & $1.521: 122$ \\
\hline $2.26 \%:+21$ & $2.351: 1.22$ \\
\hline $2.85: 1.21$ & $3.011: 1.22$ \\
\hline $5.911 \cdot 2.1$ & $1.011: 1.3$ \\
\hline $4.131 \% 12.1$ & 2.3318123 \\
\hline $1.971: 1 \cdot 2.1$ & $3.611: 1 . \% 3$ \\
\hline $2.031: 1.21$ & $3.2 .11: 1: 3$ \\
\hline $2.161 \% .21$ & $5.1(1: 1: 73$ \\
\hline $1.2 .11: 1.21$ & $2.311: 1: 3$ \\
\hline 2. 32.1:1?1 & $3.5: 1: 1 \% 3$ \\
\hline $1.581: 12.1$ & $7.77 !: 12.2$ \\
\hline $1.70 \%+? .1$ & o.2.1:1:1:?"? \\
\hline $4.2 .11: 1.23$ & 4.J.oiı:?: \\
\hline $1.2 \% 1: 1 \% 4$ & 1. . $1: 1: 1 \% 2$ \\
\hline 1...321:1:216 & 3.:39l:1.71. \\
\hline $6.6 .2: 1: 123$ & $7.3(1: 1: 1:(1)$ \\
\hline $2.101: 1.313$ & $-n$ \\
\hline 5.(1)1:1?:? & $-\cdots+\cdots \cdots \cdots$ \\
\hline 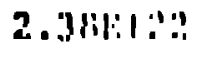 & $\cdots$ \\
\hline 1. . .j/1:1:1.1. & -............... \\
\hline
\end{tabular}



C. P. Knowless
$-4-$
Apr11 5, $3.97 G$

TABLE III

GMMSA-RAY OUTH'UT

Energy Group (fiev)

$9 \quad-10$

$8-9$

$7-8$

$6-7$

$5-0$

$4-5$

$3-4$

2. -3

$1-2$

$0.5-1$

$0.1-0.5$
Cinn:mo - Rily Outrute

Ent!liu? Liticloy

$2.371 \% 1 \% 0$

3. $2.51:+20$.

9.22:-3. 9

$3.07 E+20$

$2.3 \%+1 \% 2$

1.01.L.+2.2

$0.38 \% 21$.

3.651:21 21

4.5481 .71

2. $05 i x+21$

1.1.1.1.1.???

$4.831:+2.2$

1.751:1.?\%

$7.371: 1.21$

4. $8191 \% 2.2$

1.041:1??2

9.091:1.2.?

1.3 31:17.?

2.191:1??

2. 801:-1.22

$4.991: 1: 21$

1.2.2.1.2. 


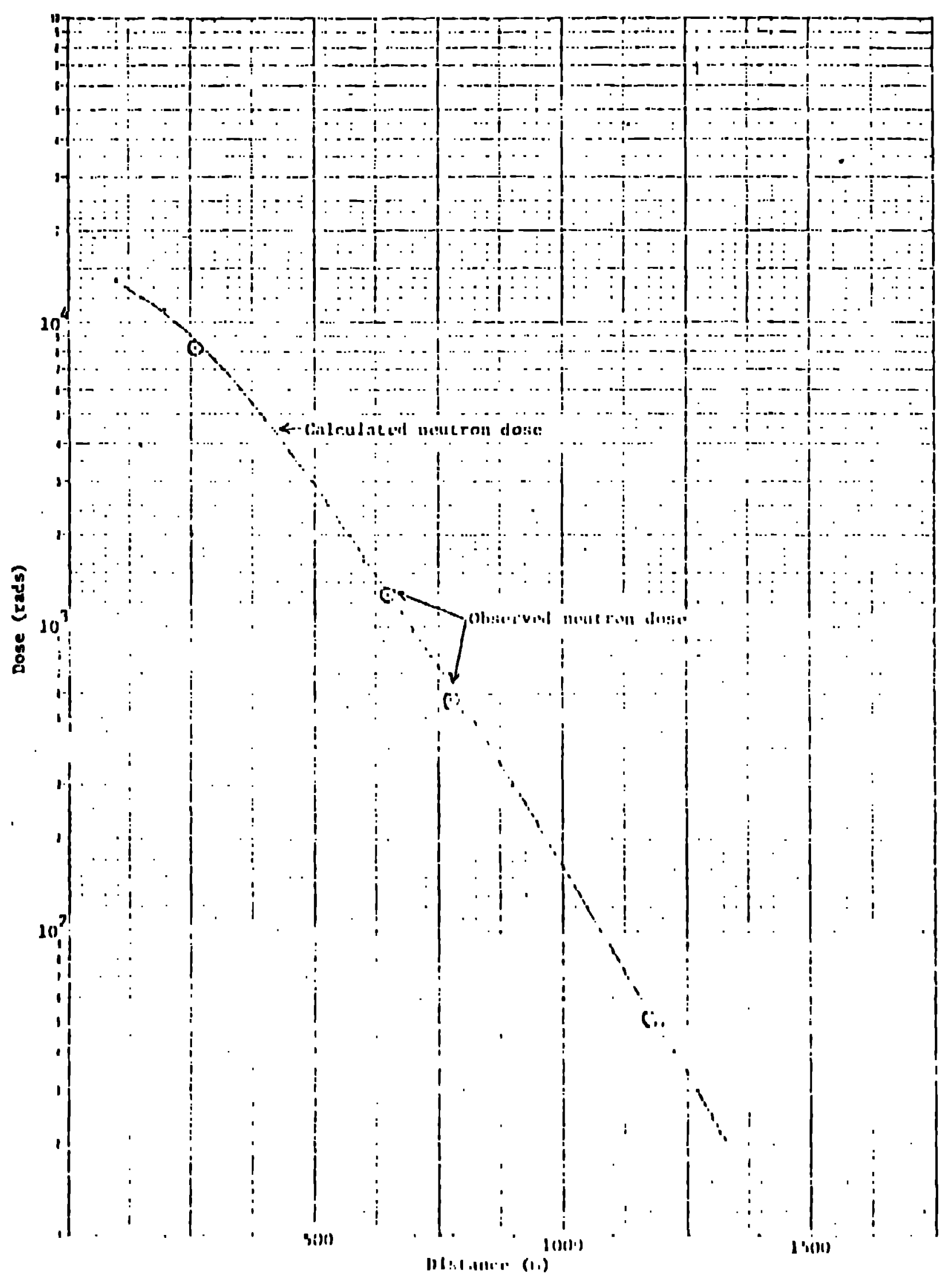

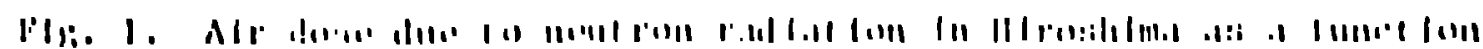

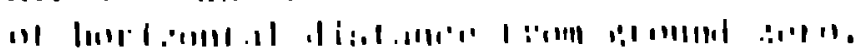




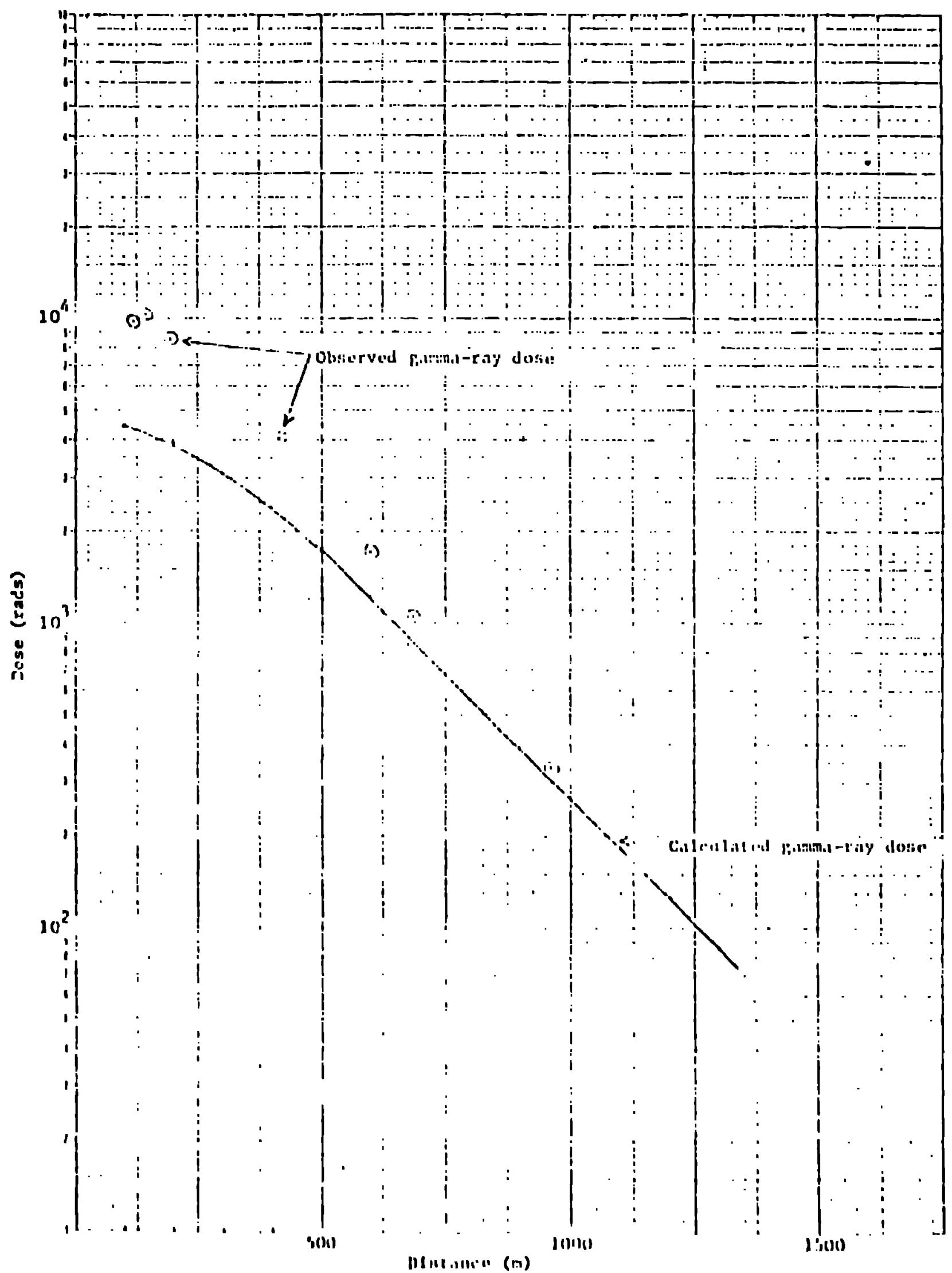

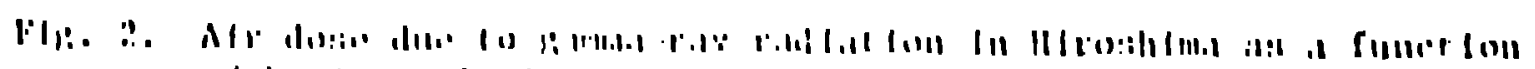

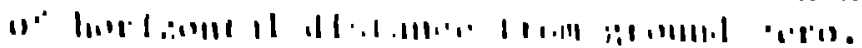




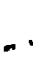

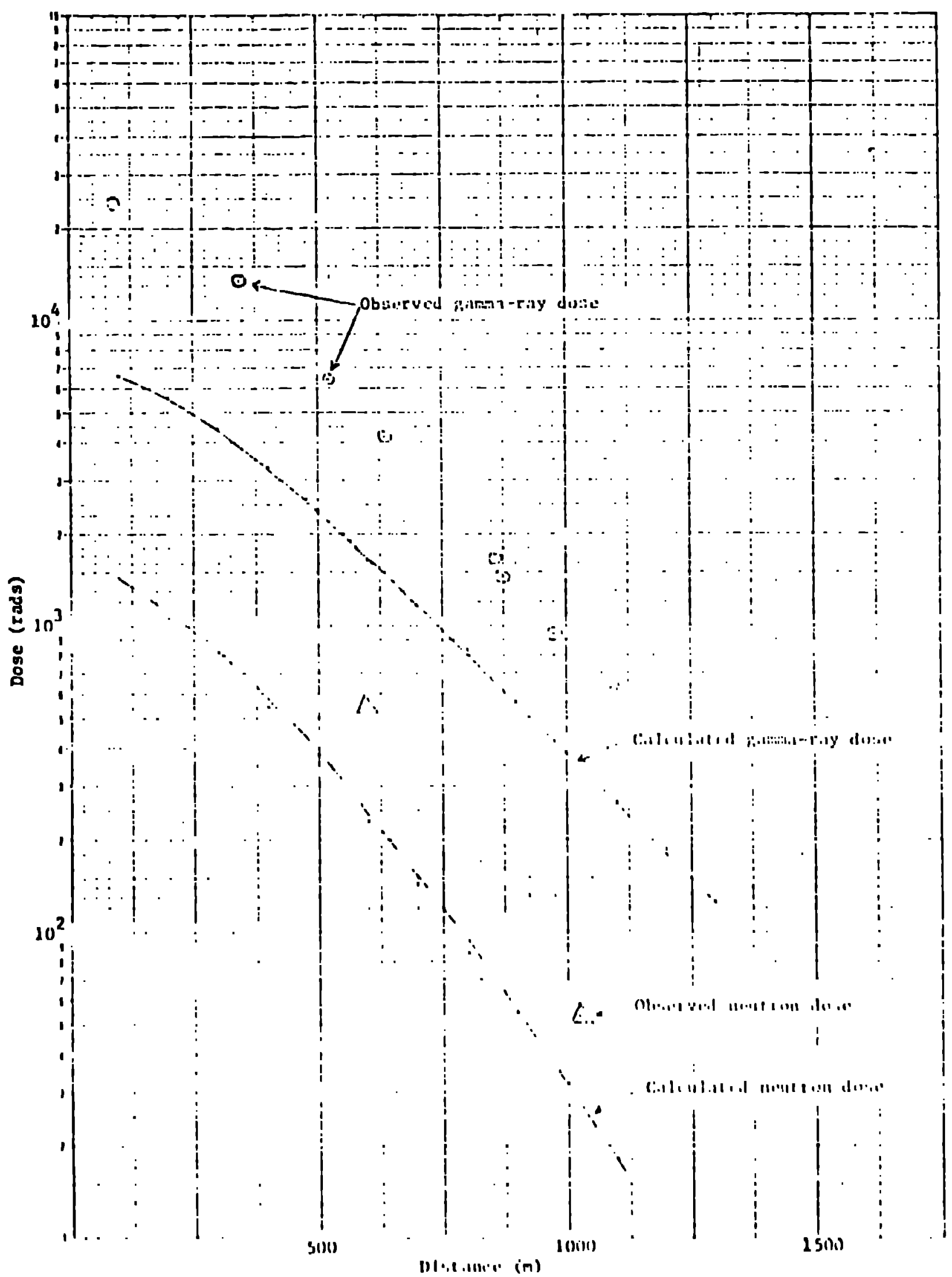

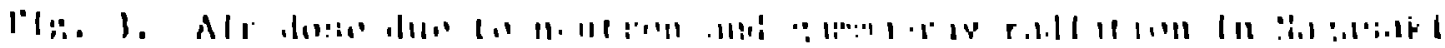

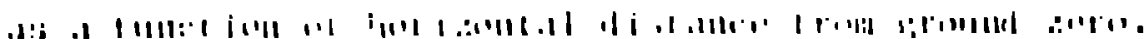


There are several possible explanations for these discrepanctes. The Fat Man device (Nagnsak1) had a very large output of lou-energy neucrons. The transport of these neutrons and the resulting gamma-ray production In the alr involves times which are comparable with the cime for fireball growth. The effect of the fircball growth was not considered in the calculations. Another possibility is that the yield of Little Boy (IIIrosh1ma) was considerably less thui calculaced, as suggested in some of the references in Table $I$. This would result in both caiculations being lower than the observed values which would suggest an error in the conservation factors of activation to dose or nectron flux to dose. Finally, there is some question of the height oi burst for Fat Man. These calculations assumed that it was $580 \mathrm{~m}$. If the height of burst was only $500 \mathrm{~m}$, the observed and calculated doses would be in much better agrcement.

These discrepancles can probialy be resolved. John Malik (J-DOT, LASL) has mentioned to me that other dose meitsurements exist on devices that were elther the sno or very siailar to the Fat Man. By comparing

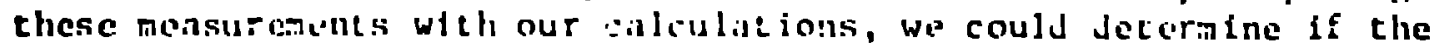

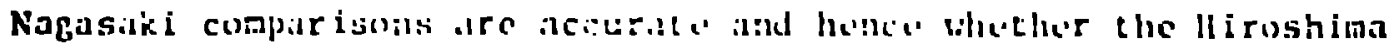
comparisons are valid at the calculaded yiuld.

I hope thit: information will be useful tu you.

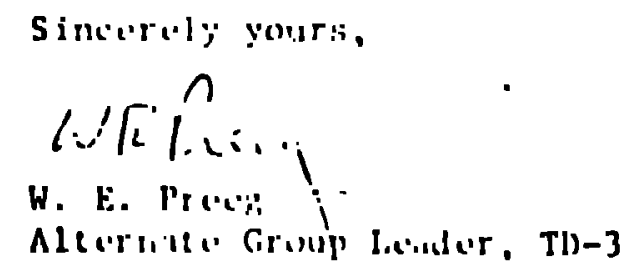

cc: Mafor! A. Sk.1rup,a, D:A

Caple. R. S. Wiley. Artik:

J. A. Auxler, H:i.

J. v. Pare, Hisi.

‥ J. Deill, HI, REDA

E. A. Serialer. sis

(.. T. VIk, l.l.l.

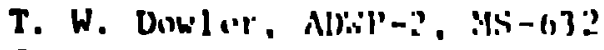

J. M,llk, J-i)(TT, RS-1): :

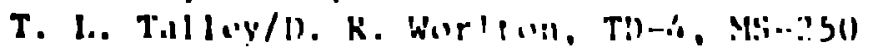

R. M. Hen!:(on, Ti- $\therefore$ M! $\because \because 1)$

P. P. Whl1 l(1),

ISI)-T (?) 